\title{
Efficiency of Using Smart-Mobile Phones in Accessing Agricultural Information by Smallholder Farmers in North Kordofan - Sudan
}

Mohammed A. A. Hamad ${ }^{1,{ }^{*}, \text { Muneer Elyas Siddig Eltahir }}{ }^{2,}$ Adam Elradi M. Ali ${ }^{3}$, Adam M. Hamdan $^{4}$, Amgad Ahamed H. Elsafi ${ }^{5}$

${ }^{1}$ Department of Rural Extension and Training, Faculty of Natural Resources and Environmental Studies, University of Kordofan, Sudan

${ }^{2}$ Department of Extension, Training and Documentation, Institute of Gum Arabic Research and Desertification Studies, University of Kordofan

${ }^{3}$ Department of Agricultural Extension and Training, University of Gezira, Sudan

${ }^{4}$ Faculty of Developmental Studies, Peace University, Sudan

${ }^{5}$ Abu Habil Scheme, Ministry of Agriculture, North Kordofan State, Sudan

*Corresponding author Email: abugitaf2013@gmail.com

\begin{abstract}
The access to agricultural information in Sudan continues to be challenging to farmers due to use of inadequate sources and traditional extension approaches. The rapid growth of smartmobile phones usage in developing countries resulted in several advantages compared to other alternatives in term of costs, geographic coverage and ease of use. This research was conducted in North Kordofan Sate to explore the role of smart-mobile phone in accessing agricultural information. Primary data were obtained by structured questionnaires and focus group discussion through participatory rural appraisal and observation while secondary data were collected from scientific journals, books and authenticated web sources. A number of 230 respondents (10\% from total farmers) were interviewed and five focus group discussions were done. Statistical Packages for Social Science (SPSS) version 22 was used to analyze the data with aid of descriptive statistics and Chi-squire Test. The result indicated that most of the respondents fall in age group between 21-40 years, and they depend on farm activity. There was $90 \%$ of farmers processed mobile phone since more than three years ago, $90.8 \%$ continuedto use smart mobile phone to access agricultural information and showed positive contribution towards income generation. The results also revealed that there was positive perception towards using mobile phones which showed more efficient in use than radio and TVs. The results showed great advantages of using smart mobile phone where 75.2 $\%$ of respondents preferred to get agricultural information, logistics and other needs through successful communication in the mid of agricultural season. Results of Chi-squire test showed significant differences between the parameters tested. The study recommended that farmers should be connected with mobile phones to admit ease communication with agricultural extension offices and quick access to their needs and logistics.
\end{abstract}


Keywords: Agricultural information, smart-mobile, stakeholder farmers, Sudan

\section{Introduction}

Agriculture is the main activity of the communities in Sudan[1], the Sudanese agricultural sector contributes about $36.5 \%$ to the country's GDP[2].Access to information is even more critical to develop rain fed agricultural [3]Improvement in agriculture is possible with the adoption of new and modern farming techniques. Government and non-governmental organizations have realized this to boost up agricultural production, Further, information delivery is a key task of government and it is their responsibility to keep farmers updated[4]Information and Communication Technology (ICT) plays a vital role in disseminating agricultural information and keep farmers connecting with agricultural value chain[5], and extension agent has a strong reliance on information exchange among farmers [6]to improving productivity at the village level[7]. Due to specialization of smallholder farmers by low average yield, there is a great extent limited agricultural transformation strategies implemented over the years this could be attributed to rely on third parties for agricultural information[8]. Information and communication technologies (ICTs) are unique tools against poverty alleviation [9] this may enhance agricultural advisory services. The need for better information, through mobile phones can be considered as the perquisites for the farmers to benefit from using mobile communication technologies to improve need access [10] as well as a tool for development at local and community levels[11] Recently, using modern technologies is considered as an appropriate for farmers' need and increase in out-put of crops[12], these approaches increase farmer's basic knowledge and ability to make their own choices and decision on particular technologies[13]. Farmers assume to become key players in technology identification, generation, and dissemination[14] if quick exchange of agricultural information between the extension agents and farmers are integrated [15] A major effort of government aimed at raising the agricultural productivity and competitiveness of smallholder farmers in Sudan involved reforming and implementing agricultural adversary services [16]. Agricultural extension could be expected to enhance rural development through significant improvements in supporting capacity building amongst farmers and raise awareness on the existence of various sources of knowledge [3] to enable them use the information they access effectively [17], in Sudan extension service face some challenges due to socio- economic changes[18] and inappropriate communication channels to be used by extension personnel[19]. They suggest two types of 'gaps' contribute to the productivity differential: the technology gap and the management gap[20] Against this backdrop[21], the main research question here is - to what extend using smart mobile phone influence farmers 
in North Kordofan in accessing useful agricultural information? This research paper aims to identify the updated agricultural information shared through mobile phones, to determine the appropriate time of receiving agricultural information, and to explore the challenges encountered using mobile phones in area.

\section{Study site and Methods}

\subsection{Study site description}

North Kordofan State is located in the central part of Sudan[22]Arid and semi-arid zones that cover the largest part of this State[23]. It lays between latitudes $12^{\circ} 10^{\prime}$ and $16^{\circ} 30^{\prime} \mathrm{N}$, longitudes $27^{\circ}$ and $32^{\circ} 35^{\prime} \mathrm{E}$ is divided into eight localities[24]Figure1.Theaverage annual rainfall is about $300-\mathrm{mm}$, consisting of storms of short duration between July and September with the highest rainfall generally occurring in August[25]. The soil of the site lies within the sand dune area locally known as "Goz" soil. The site is naturally dominated main grasses include namely Huskneet (Cenchrusbiflorus), Shuleny (Zorniaglochidiata) and Bigual (Blepharislinarifolia). Such tree as Humied (Sclerocaryabirrea), Higlig (Balanites), Arad (Acacia etbaica) and Sider (Zizuphus spina). The Shrubs include Kursan(Bosciasenegalensis), Usher (Calotropis), Mereikh (Polygala eriotera) and Aborakhus (Andropogongayanus) according to (MAWF, 2009)[26]The major crops grown are millet and sorghum (food crops), groundnut and sesame (cash crops) on the other site Gum Arabic production and forest and Non Timber Forest Products (NTFPs) contribute significantly to livelihood. Animal raised are mainly sheep, camels, and goats[23]
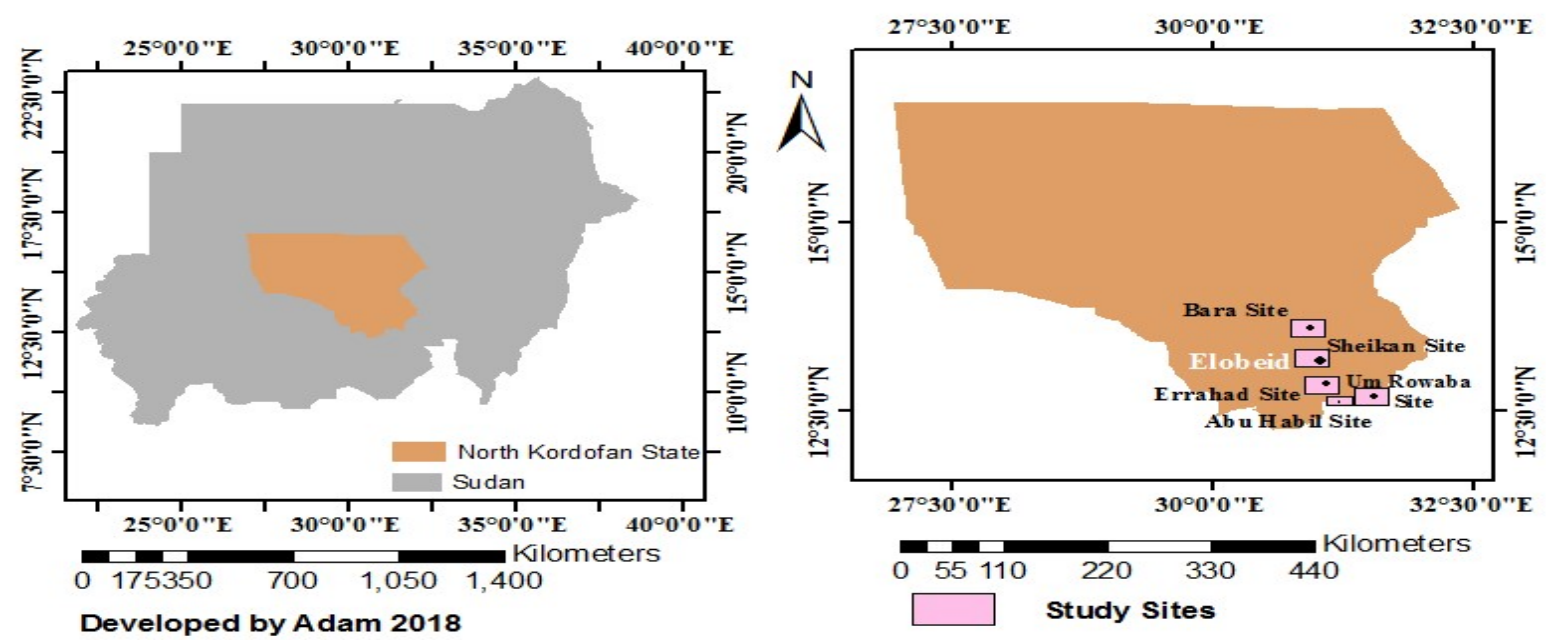

Figure 1. Location of the study area in Sudan[27]

\section{Population and sampling procedures}


The targeted populations of this study are small scale farmers using mobile phones for accessing agricultural information to improve their productivity and bridging their gap of knowledge and skill regarding agriculture in the area. A number of 918 A [28] farmers use mobile phones for access agricultural information in rural area within North Kordofan State. Purposive sampling technique was used and 230 respondents ( $25 \%$ from the total frame) were interviewed in study area based on the population intensity. 5 Focus Group Discussion (FGD) will be conducted with key informants, farmer's advisory contact.

The following table (1) shows the study site, total number of farmers in each site, \% sample size, and number of respondent in the sample.

\begin{tabular}{lccc}
\hline Study site & Total Number of farmer & \% sample size & $\begin{array}{c}\text { No. of the respondents in } \\
\text { the sample }\end{array}$ \\
\hline Sheikan & 150 & 38 \\
Bara & 180 & 25 & 45 \\
El Rahad & 96 & 24 \\
Um Rawaba & 112 & 28 \\
Abu Habil Scheme & 380 & $25 \%$ & 95 \\
\hline Total & 918 & & 230 \\
\hline Source; created & & &
\end{tabular}

Sources; created by author 2018 .

\section{Results}

\subsection{Socioeconomic characteristics}

The frequency distribution of demographic characteristics revealed that most of the respondents were in age group between 21-40 years followed by 41-60 years. This indicates that those farmers are in productive age and the number of youth was high compared to older. Gender composition consists of high presence of male (table,2), however, our results contradicted with Meera et al. (2004) who reported that young people are effective more in ICT program for agriculture [29]. Educational background of the respondents showed that $45.3 \%$ (mean of total percent) studied secondary school and majority of them were married. Analysis of income and the income sources indicated that most of the respondents generate about 2000 - 3000 SDG per month from framing sources. This output passes in line with [1] and [30] which said that farming activities represent the main occupation in developing courtiers. The results of chi-squire test indicated that there were no significant differences between educational levels and ages regarding using mobile phones in solving farmer's problems and needs (table 3 and 4 respectively). 
Table 2. Distribution of the respondent's according to demographic characteristics

\begin{tabular}{|c|c|c|c|c|c|c|c|c|c|c|c|}
\hline \multicolumn{2}{|c|}{ Characteristics } & \multicolumn{2}{|c|}{ Bara } & \multicolumn{2}{|c|}{ Sheikan } & \multicolumn{2}{|c|}{ El Rahad } & \multicolumn{2}{|c|}{ Abu Habil } & \multicolumn{2}{|c|}{ Um Rawaba } \\
\hline & & Freq & $\%$ & Freq & $\%$ & Freq & $\%$ & Freq & $\%$ & Freq & $\%$ \\
\hline Age & $\leq 20 \mathrm{yrs}$ & - & - & - & - & - & - & - & - & 3 & 10.7 \\
\hline \multirow[t]{3}{*}{ gradation } & $21-40 \mathrm{yrs}$ & 28 & 62.2 & 16 & 42.1 & 1 & 4.2 & 44 & 46.3 & 16 & 57.1 \\
\hline & $41-60$ yrs & 13 & 28.9 & 18 & 47.4 & 19 & 79.2 & 30 & 31.6 & 7 & 25 \\
\hline & $\geq 60 \mathrm{yrs}$ & 4 & 8.9 & 4 & 10.5 & 4 & 16.7 & 21 & 22.1 & 2 & 7.1 \\
\hline \multirow[t]{3}{*}{ Gender } & Male & 42 & 93.3 & 31 & 81.6 & 24 & 100 & 69 & 72.6 & 17 & 60.7 \\
\hline & Female & 3 & 6.7 & 7 & 18.4 & - & - & 26 & 27.4 & 11 & 39.3 \\
\hline & Illiterate & 16 & 35.6 & 2 & 5.3 & 2 & 8.3 & 24 & 25.3 & 4 & 14.3 \\
\hline \multirow[t]{3}{*}{ Education } & Read \&Write & 18 & 40 & 25 & 65.9 & 8 & 33.3 & 39 & 41.1 & 13 & 46.4 \\
\hline & Educated & 11 & 24.4 & 28 & 28.7 & 14 & 58.3 & 32 & 33.7 & 3 & 39.3 \\
\hline & Married & 37 & 82.2 & 29 & 76.3 & 22 & 91.3 & 79 & 83.2 & 19 & 67.9 \\
\hline \multirow[t]{4}{*}{ Social status } & Divorce & - & - & - & - & - & - & 4 & 4.2 & - & - \\
\hline & Widow & - & - & - & - & - & - & 2 & 2.1 & - & - \\
\hline & Not Married & 8 & 17.8 & 9 & 23.7 & 2 & 8.3 & 10 & 10.5 & 9 & 32.1 \\
\hline & $<2000 \mathrm{SDG}$ & 14 & 31.1 & 14 & 36.8 & 9 & 37.5 & 55 & 57.9 & 13 & 46.4 \\
\hline \multirow{4}{*}{$\begin{array}{l}\text { Average } \\
\text { income per } \\
\text { month }\end{array}$} & $2000-3000$ & 27 & 60 & 18 & 47.4 & 6 & 25 & 27 & 28.4 & 10 & 35.7 \\
\hline & SDG & & & & & & & & & & \\
\hline & $>3000 \mathrm{SDG}$ & 4 & 8.9 & 6 & 15.8 & 9 & 37.5 & 13 & 13.7 & 5 & 17.9 \\
\hline & Farming & 38 & 84.4 & 37 & 97.4 & 24 & 100 & 88 & 92.6 & 26 & 92.9 \\
\hline \multirow{3}{*}{$\begin{array}{l}\text { Source of } \\
\text { income }\end{array}$} & Labour & 6 & 13.3 & - & - & - & - & 1 & 1.1 & 1 & 3.6 \\
\hline & Trading & 1 & 2.2 & 1 & 2.6 & - & - & - & - & - & - \\
\hline & Employer & - & - & - & - & - & - & 6 & 6.3 & 1 & 3.6 \\
\hline
\end{tabular}


Table 3. Chi-square Test for significant between efficient of mobile phones in solving farmers problems and needs and educational level

\begin{tabular}{|lcccccc|}
\hline & & \multicolumn{3}{c}{ Educational level } & Total & Sig. \\
\cline { 2 - 5 } & & Illiterate & Read \& Write & Educated & \\
\hline $\begin{array}{l}\text { Efficient of Mobile } \\
\begin{array}{l}\text { Phones in solving } \\
\text { farmers problems } \\
\text { and needs }\end{array}\end{array}$ & 47 & 101 & 77 & 225 & .963 \\
\cline { 2 - 6 } & $\begin{array}{l}\text { Efficient } \\
\text { Efficient }\end{array}$ & 1 & 2 & 2 & 5 \\
\hline Total & & 48 & 103 & 79 & 230 \\
\hline
\end{tabular}

$P \leq 0.05=$ significant, indicated by Chi-square Test: source; field research (2018), $X^{2}$ value $=.075$

Table 4. Chi-square Test for significant between efficient of mobile phones in solving farmers problems and needs and age of respondents

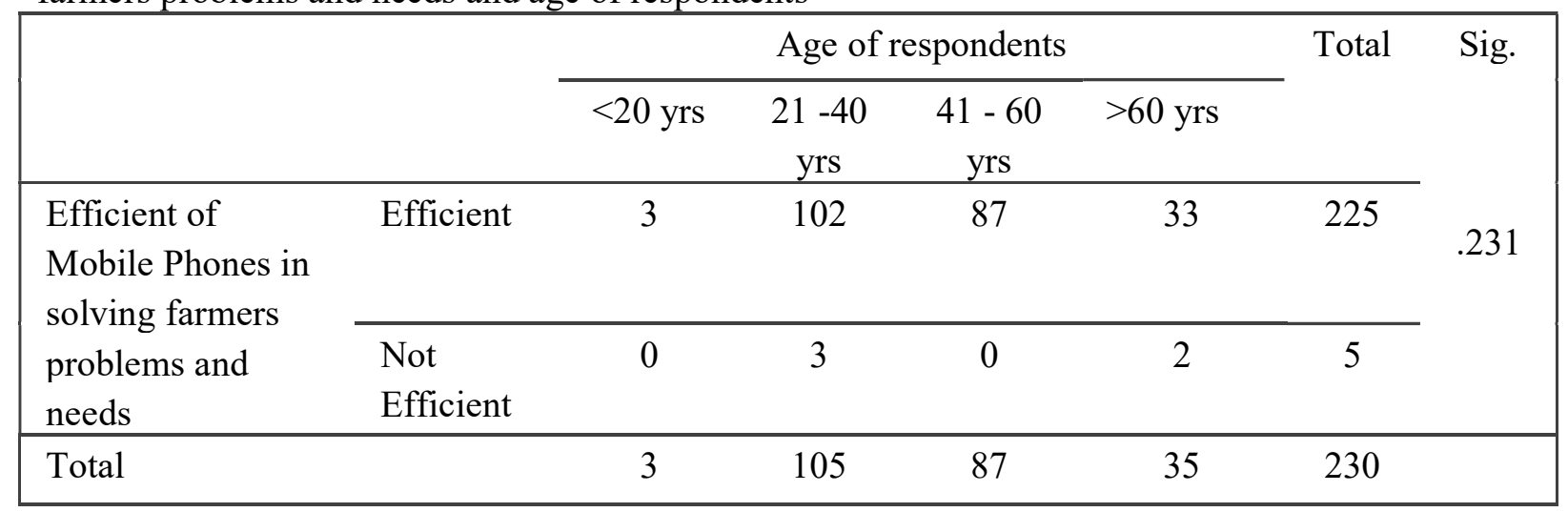

$P \leq 0.05$ = significant, indicated by Chi-square Test: source; field research (2018)

$X^{2}$ value $=4.293$

\subsection{Ownership and reason of possessing mobile phone}

Recently mobile phones are used by a broader smallholders farmers than computers[8] Prices of mobile devices are falling and become affordable even for the poorest (World Bank, 2011a). As a result the number of mobile phone subscriptions in developing countries has increased from 1.213 billion to 5.235 billion between 2005 and 2013[31]. The results addressed that nearly $90 \%$ of farmers get their mobile phone for more than three years, figure 2 and proper access to knowledge is not significantly to the type of mobile phone, table 5. This trend has also been spread into the farmers witch realized the importance of using mobile phones in life [32] the highest subscription was noticed in the year 2008 while in the year 2000- 2001 the highest percentage change (149.3\%) was realized [33]. 
On the other hand majority of farmer used mobile phone for social and business purposes, figure 3, moreoverintable6it was stated the highly significant differences between frequent use of mobile phone and farmer needs. In literature it was found that farmers used intensively mobile phone for different purposes[8] A majority of farm households in developing countries owned mobile phones [34]. The results also showed that vast respondents $90.8 \%$ in average were continuously used smart mobile phone to access agricultural information cited in figure 4. This in line with [10], [35] and [9]stated that new information services based on mobile communication technology provide opportunities to linking farmers in the agricultural value chain effectively [5].

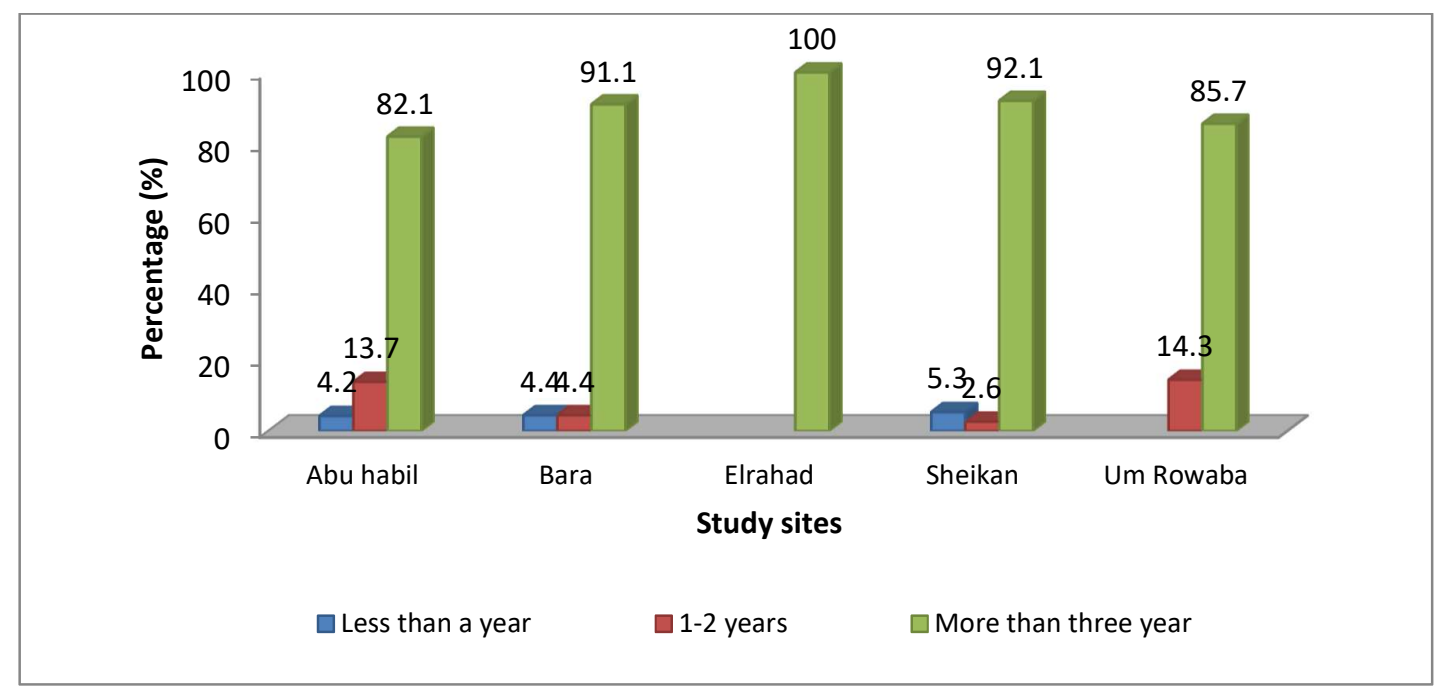

Figure 2.Farmers experience in using smart-mobile phones (years)

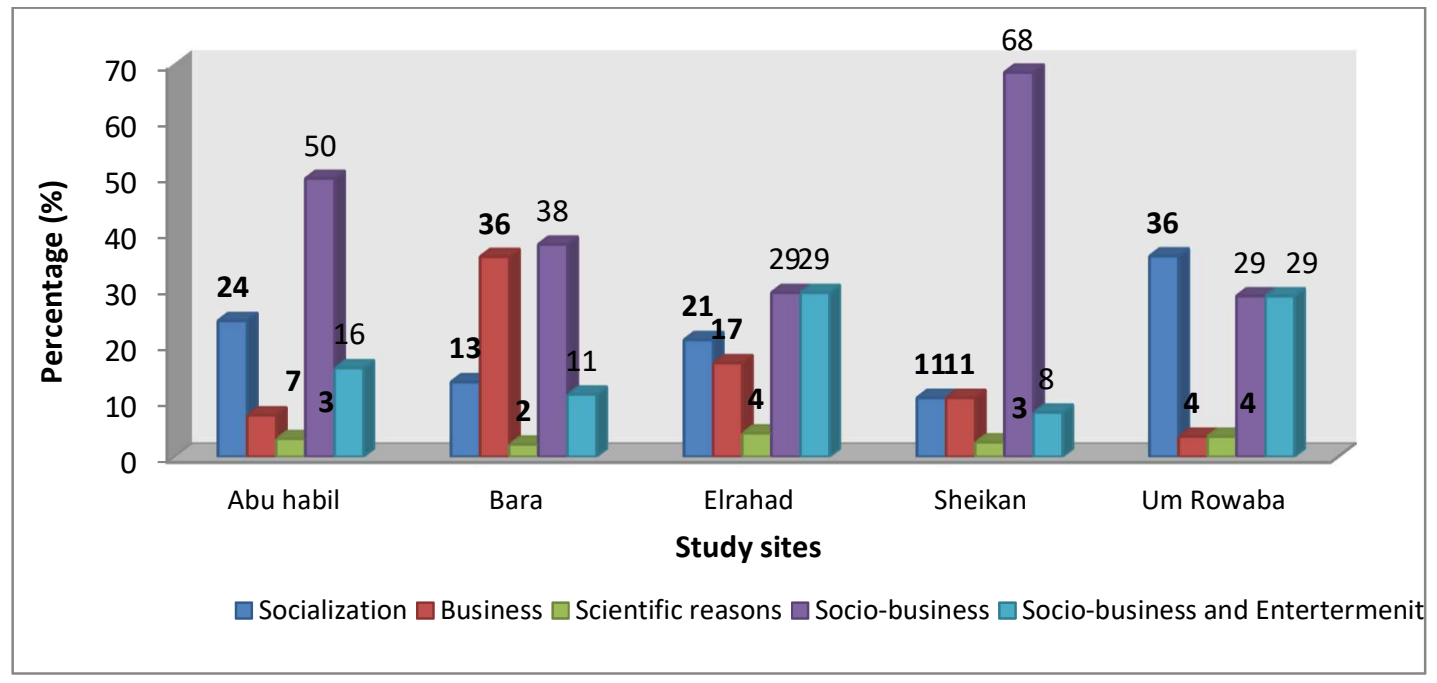

Figure 3. Reasons behind owing smart-mobile phone 


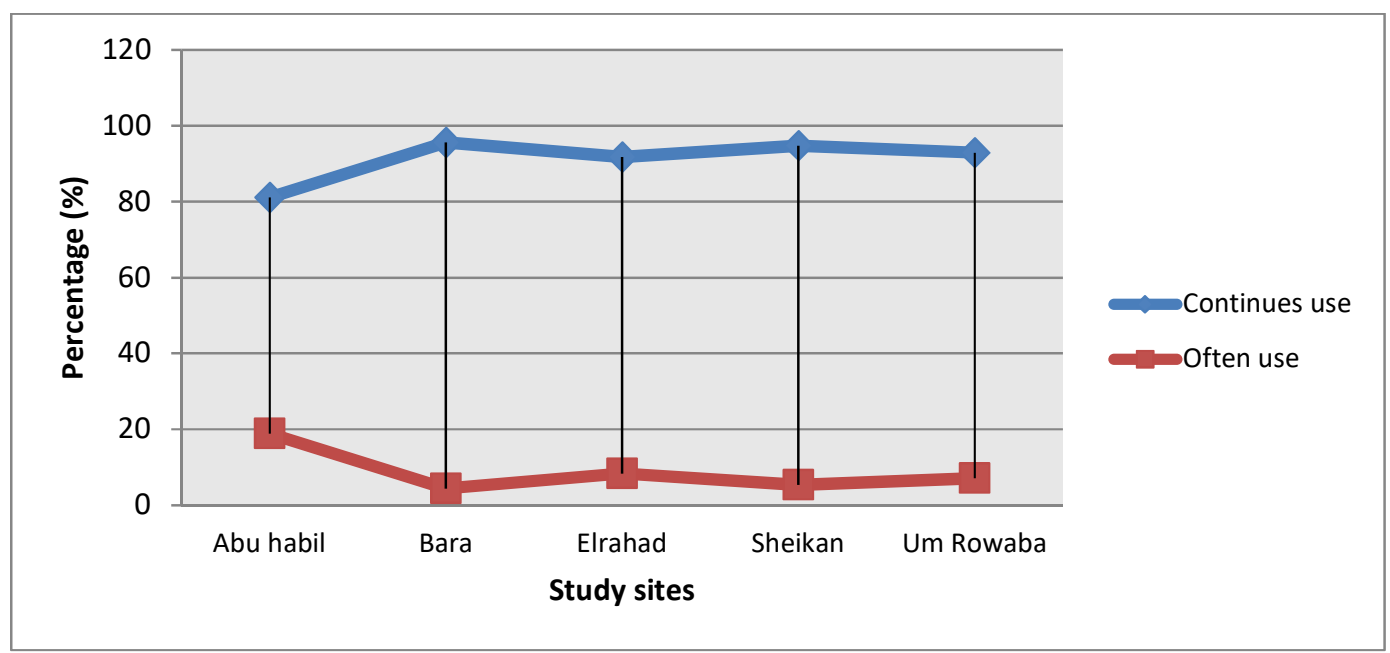

Figure 4. Use patterns of smart-mobile phones for accessing agricultural information

Table 5. Chi-square Test for significant between using mobile phones in access agricultural information and type of the mobile

\begin{tabular}{|c|c|c|c|c|c|c|}
\hline & & \multicolumn{3}{|c|}{ Type of the Mobile } & \multirow[t]{2}{*}{ Total } & \multirow[t]{2}{*}{ Sig. } \\
\hline & & Normal & Smart Mobile & Both & & \\
\hline \multirow{2}{*}{$\begin{array}{l}\text { Frequency of Using } \\
\text { Mobile Phones in } \\
\text { Access Agricultural } \\
\text { Information }\end{array}$} & Continues use & 132 & 42 & 30 & 204 & .278 \\
\hline & $\begin{array}{l}\text { Not continues } \\
\text { use }\end{array}$ & 20 & 5 & 1 & 26 & \\
\hline Total & & 152 & 47 & 31 & 230 & \\
\hline
\end{tabular}

$P \leq 0.05=$ significant, indicated by Chi-square Test: source; field research (2018)

$X^{2}$ value $=2.559$

Table 6. Chi-square Test for significant between efficient of mobile phones in solving farmers problems and needs and frequency using mobile phones

\begin{tabular}{|llcccc|}
\hline & & \multicolumn{2}{c}{$\begin{array}{l}\text { Frequency of Using Mobile Phones } \\
\text { in Access Agricultural Information }\end{array}$} & Total & Sig. \\
\cline { 2 - 5 } & & continues use & Not continues use & \\
\cline { 2 - 5 } $\begin{array}{l}\text { Efficient of Mobile } \\
\begin{array}{l}\text { Phones in solving } \\
\text { farmers problems } \\
\text { and needs }\end{array}\end{array}$ & Efficient & 203 & 22 & 225 & .001 \\
\cline { 2 - 5 } & Not & 1 & 4 & 5 \\
\hline Total & Efficient & & 26 & 230 \\
\hline
\end{tabular}

$P \leq 0.05=$ significant, indicated by Chi-square Test: source; field research (2018)

$X^{2}$ value $=24.056$ 


\subsection{Perceptions towards using smart mobile phones}

The new agricultural technologies are diffusing through different channels of daily life at a much faster than ever before[12]mobile phones are also regarded as potentially powerful and well-suited for the African agrarian communities [33]. The finding in figure 5,6 and 7 showed that allrespondents fully agree with the adoption of using mobile phone (smart or normal)in agricultural process focusing on the agriculture value chain[36]. Studies show that Ethiopia has the largest agricultural extension system in Sub-Saharan Africa and depend highly on ICT[37]. The results extend to indicated that farmers beside using mobile phone they depend on others source of getting agricultural information these are visiting extension offices, listening to radio programs, friends and relatives, TVs and agricultural association respectively and they perceived it very good in case of urgent, figure 8and 9.

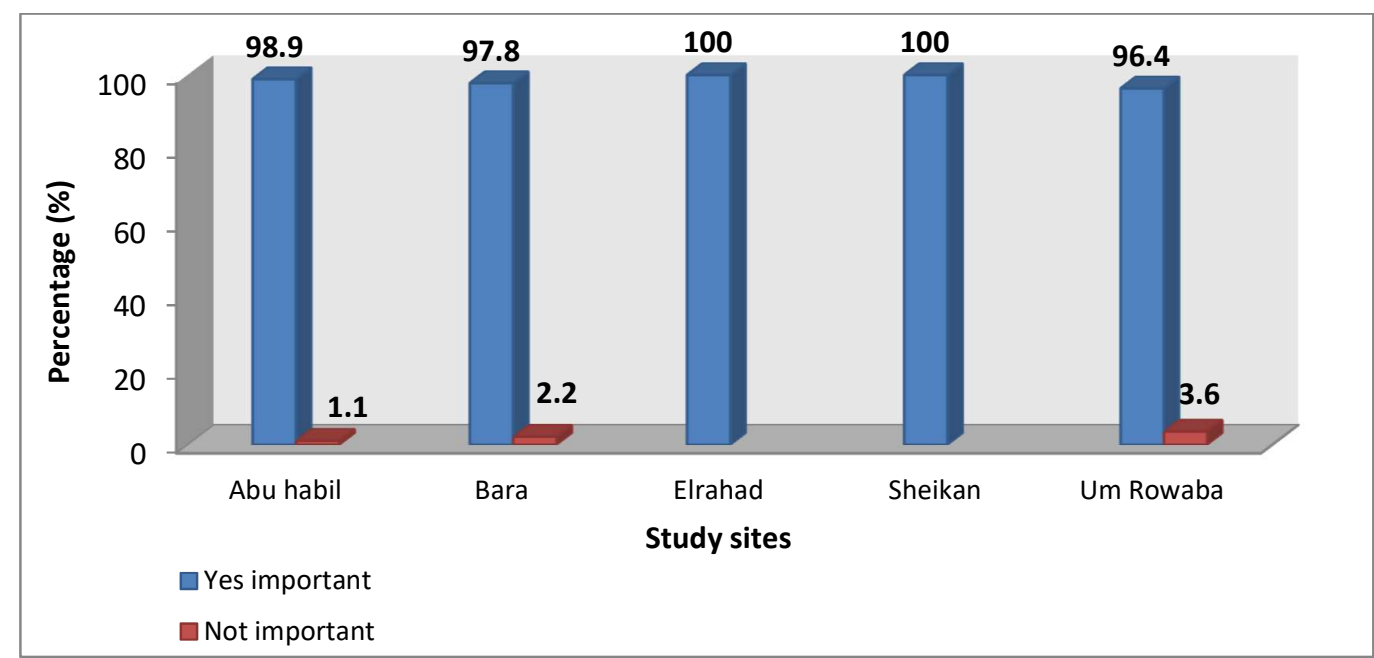

Figure 5.Farmers perception toward importance of smart-mobile phones in delivering agricultural information

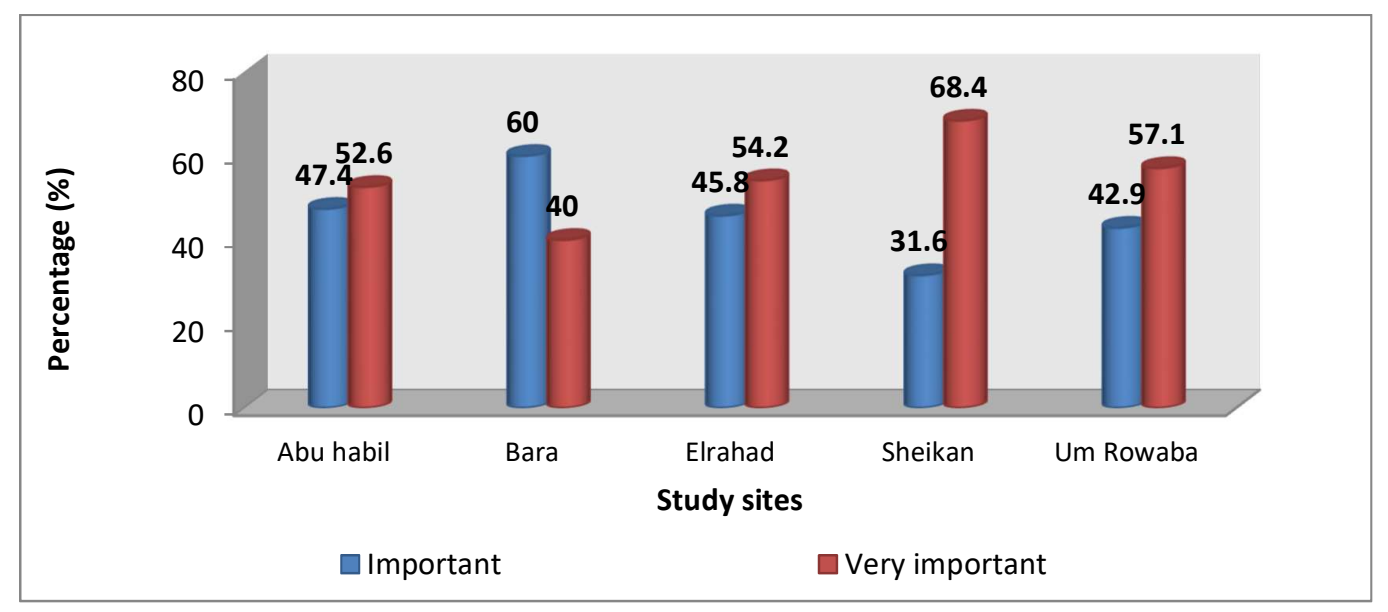

Figure 6. Farmers vision toward connecting farmers with smart-mobile phone 


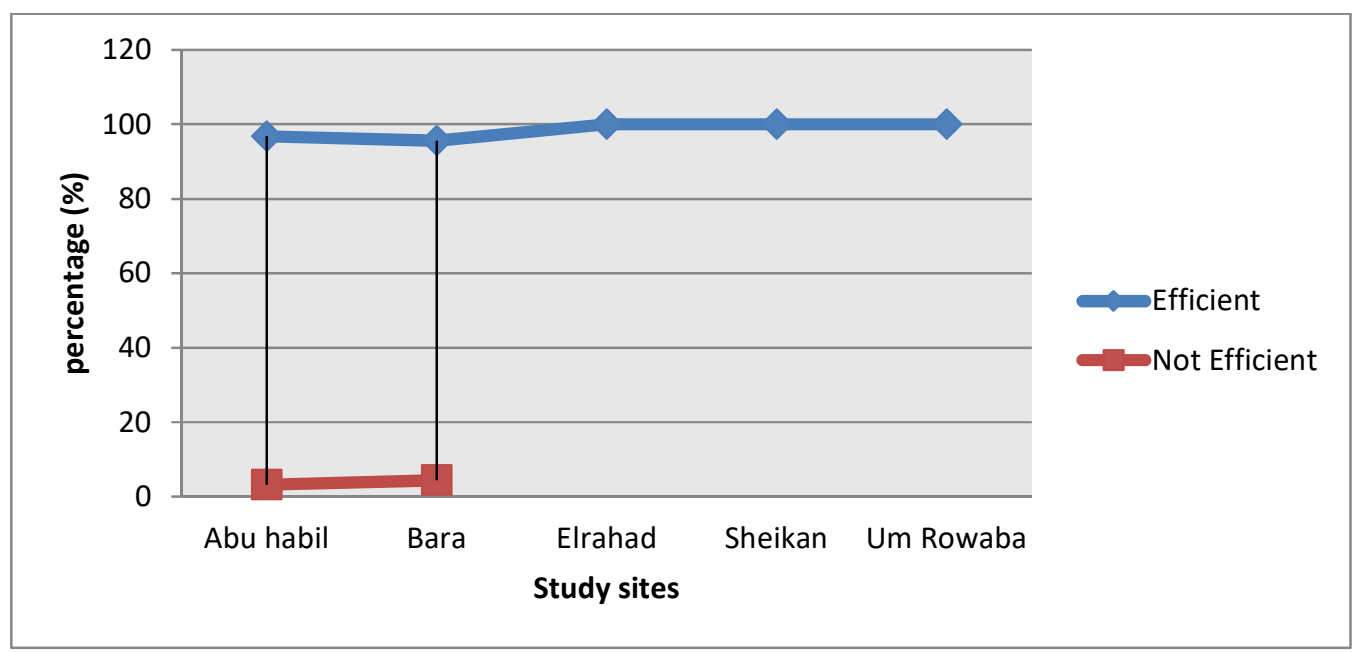

Figure 7. Respondent's assessment on the efficiency of smart-mobile phones in agricultural field

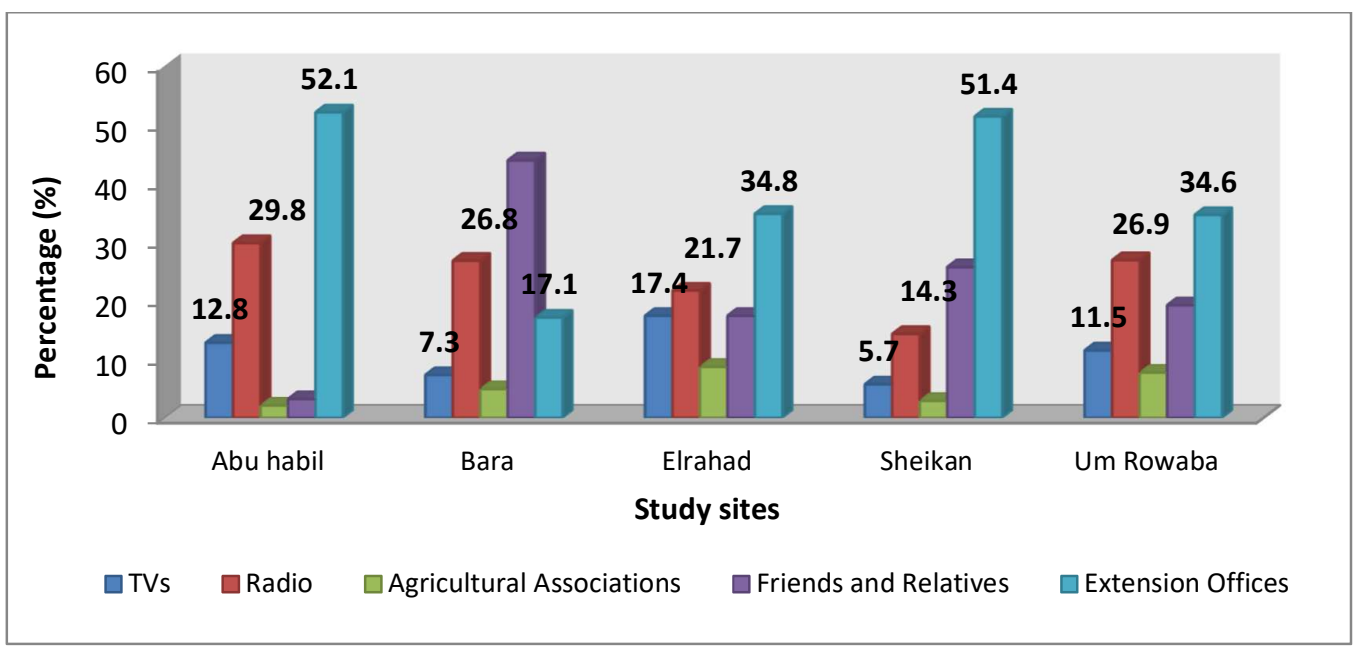

Figure 8.AdditionalSources of accessing Agricultural Information

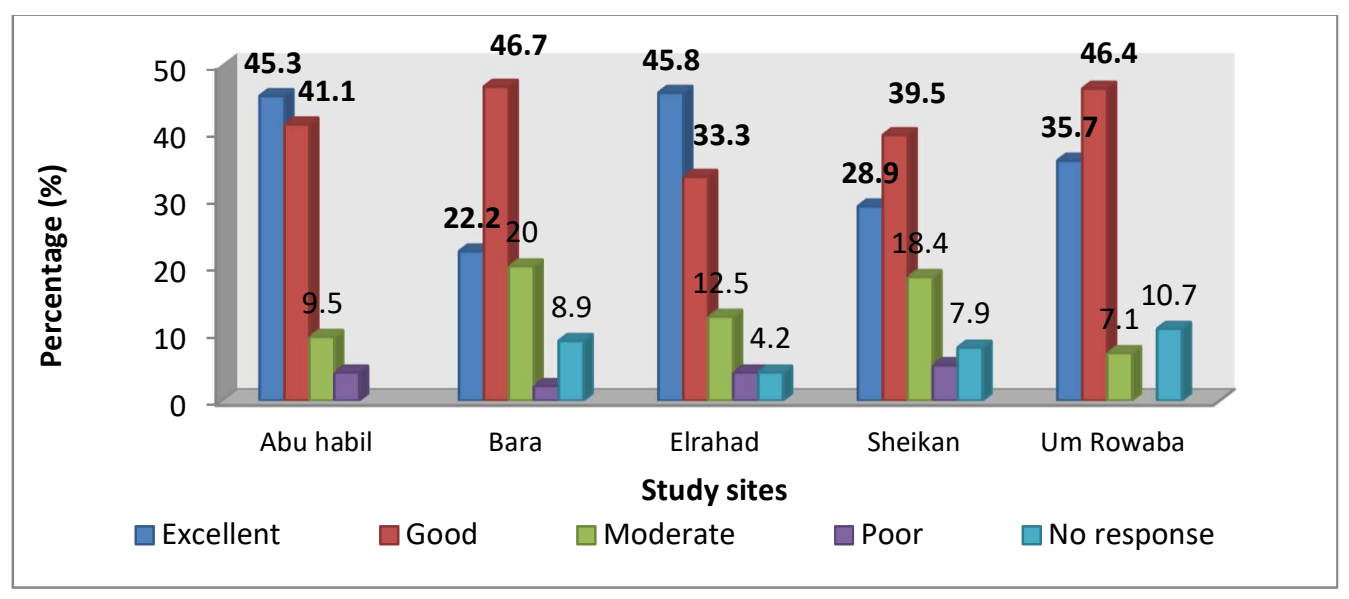

Figure 9. Farmers perceptions toward the additional sources of information in agricultural 


\subsection{Comparison and pattern of sharing information}

A range of information transfer techniques has been reported in the literature that quick access to information and services are important to agricultural revaluation[13] the Results depicted that the using of mobile phone in accessing agricultural information is highly efficient than using radio and TVs, figure 10.This mainly due to insufficient old communicating tools [15] and poor access to information[17] and in line with [12] above cited, figure 11 1nd 12 ,Furthermore, success of the green revolution in Asia, African countries need to ensure that agricultural productivity be raised in a sustainable way[38]. On the other hand the finding showed that $85.1 \%$ of the respondents communicate through voice call as frequent pattern of agricultural information sharing, figure 13. [39] Stated that more and more people gain access to information through voice call. [40] Argue that the farmers were using other means to access agricultural production information these included the use of the internet and the networks and linkages with other farmers to access agricultural production information. The results extend to revealed that vast respondents $75.2 \%$ in average they prefer to get their need through successful communication in the mid of season to ensure high yield, figure 14.Many farmers in developing countries have access to a growing number of agricultural services through their mobile phones (m-services)[41] and has significantly impacted with pattern of sharing information and type of mobile phone (smart and normal) therefore lead to economic development initiatives[42], table 7 and 8.to improve the performance of agricultural extension services we need search for new models of providing ICT agricultural services to farmers this can be reached by encourage stakeholders to adopt use of new generation ICT tools to provide valuable information to farmers and traders have also been reported in India (Jensen, 2007), Niger (Aker, 2008a) and Sri Lanka (De Silva, 2010).[43]

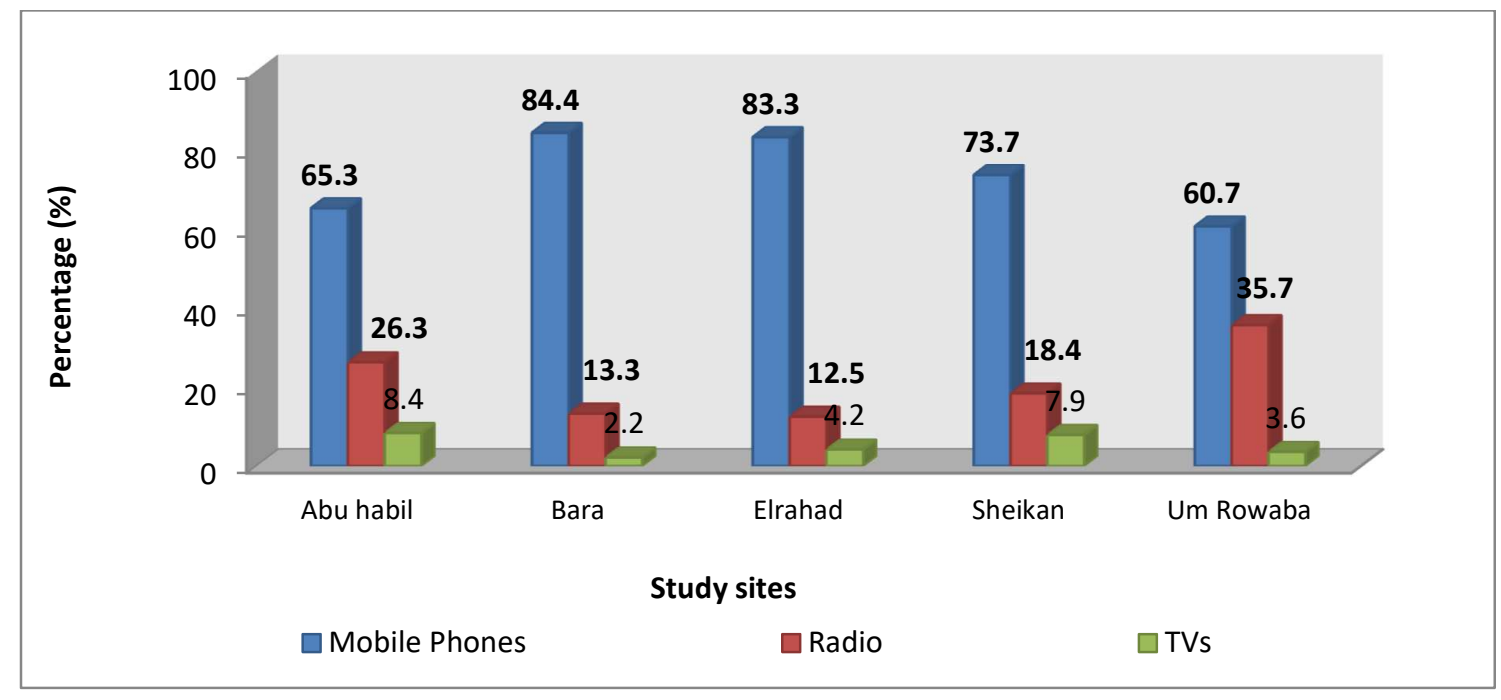


Figure 10. Efficiency of using smart-mobile phones in accessing agricultural information compared with other Sources

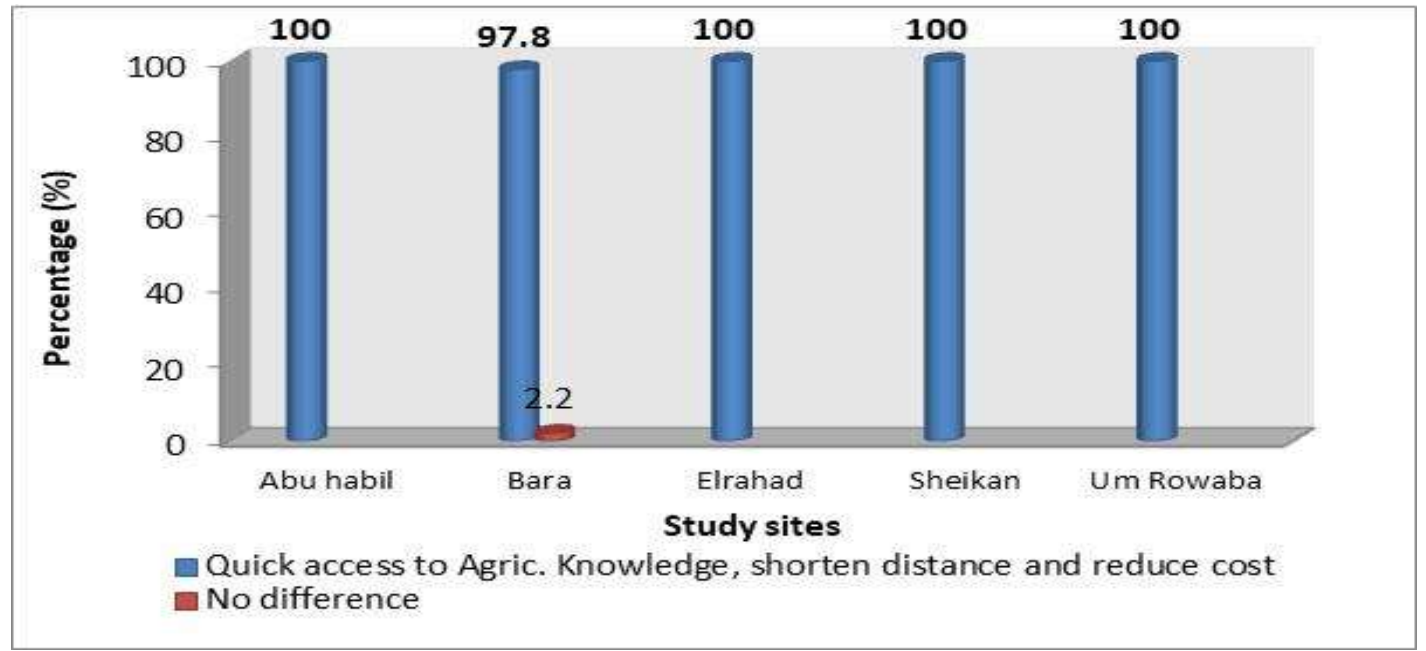

Figure 11.Functions of smart-mobile phones before and after using by farmers

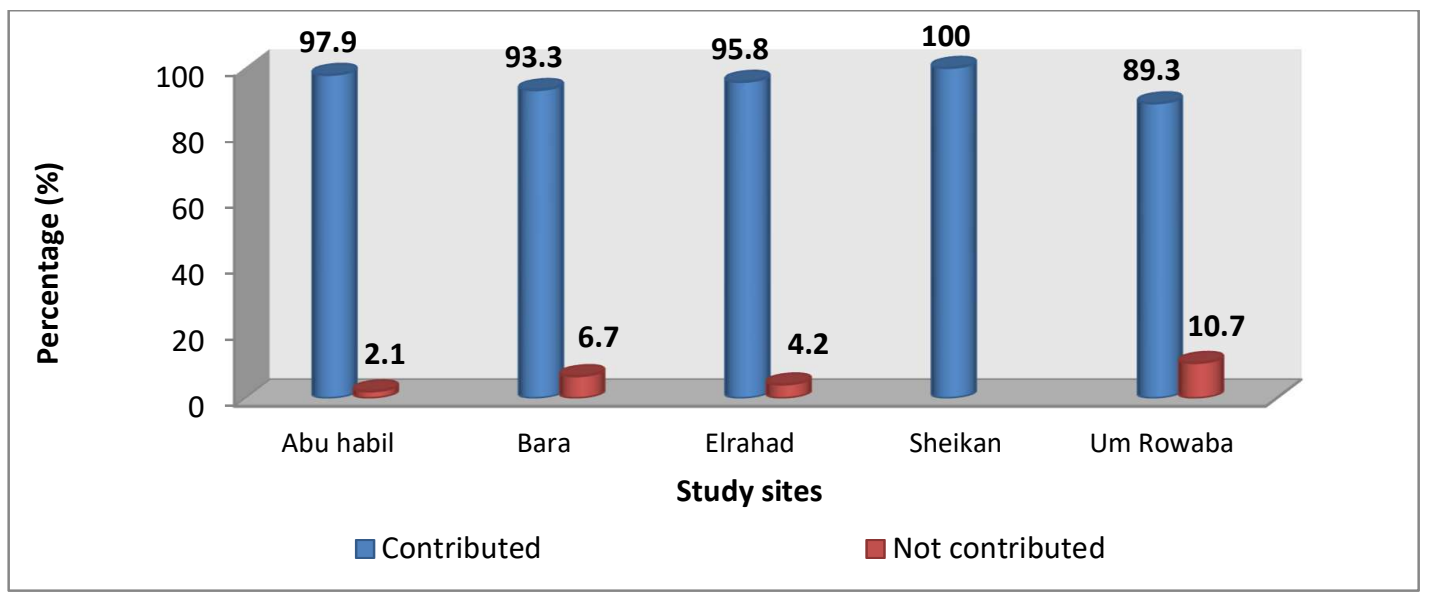

Figure 12.Farmer's perceptions toward contribution of smart-mobile phones in agricultural revolution

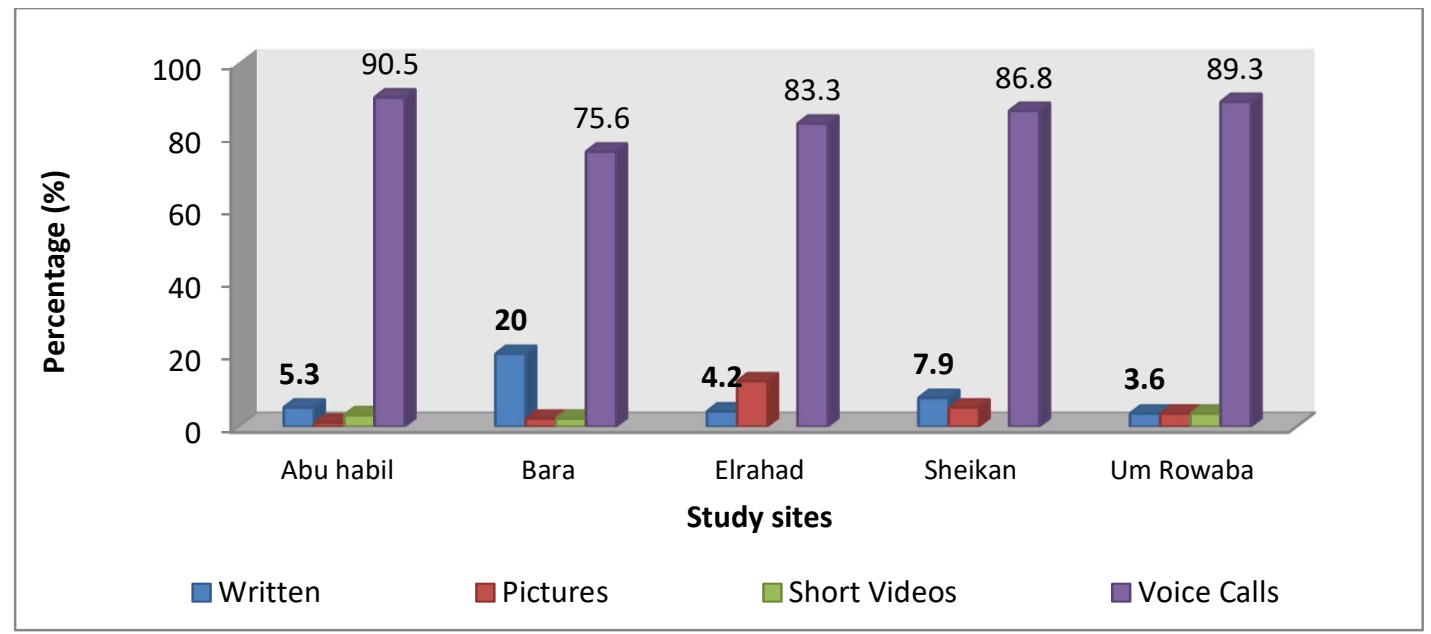


Figure 13. Patterns of sharing agricultural information through mobile phone

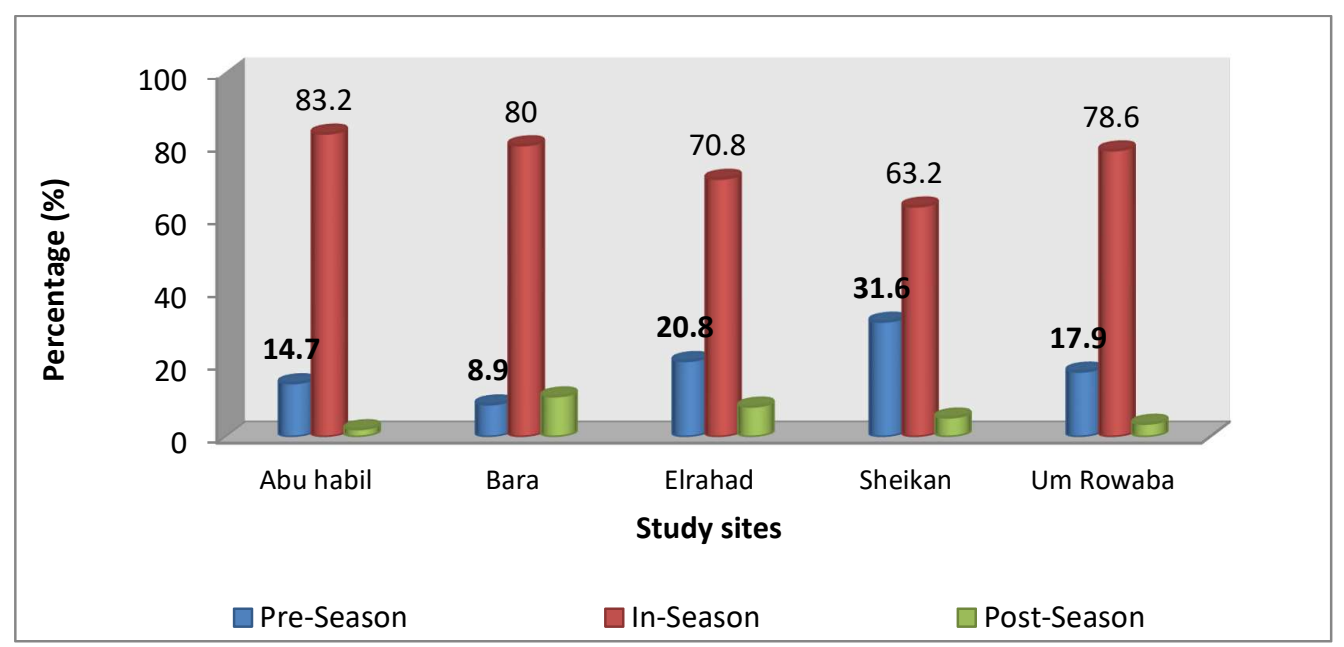

Figure 14.The appropriate time which farmers are in-needing of smart-mobile phones for agricultural purpose

Table 7. Chi-square Test for significant between appropriate time for needing mobile phones and patterns of sharing agricultural information through mobile phone

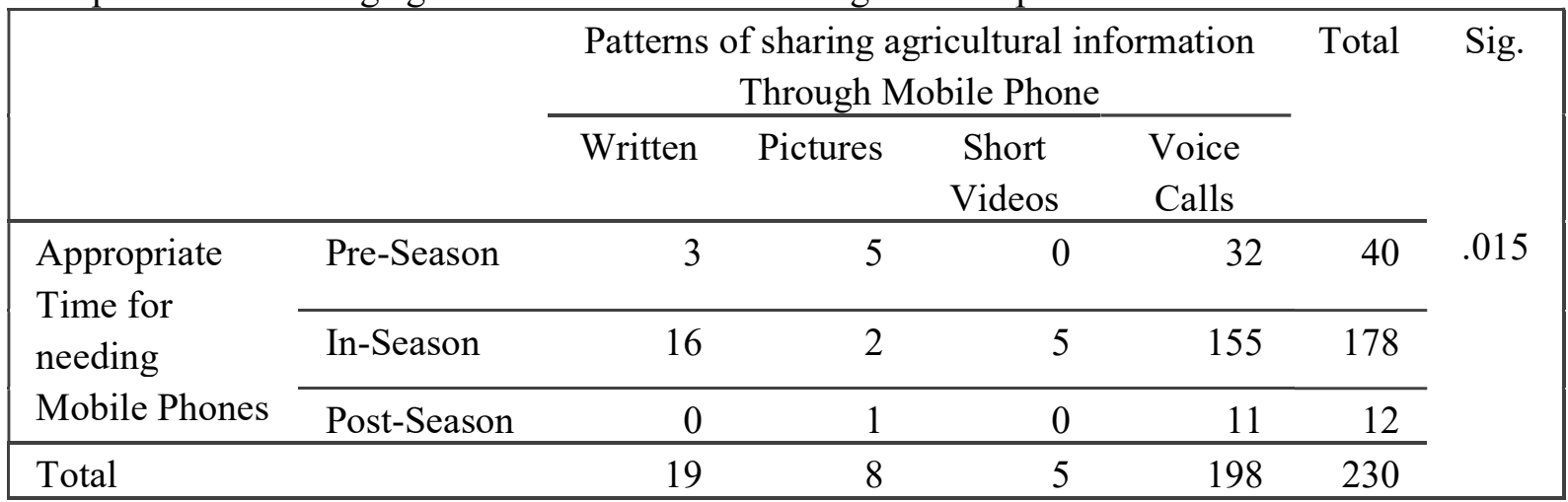

$P \leq 0.05=$ significant, indicating by Chi-square Test: source; field research (2018)

$Z^{2}$ value $=15.841$

Table 8. Chi-square test for significant between type of the mobile and patterns of sharing agricultural information through mobile phone

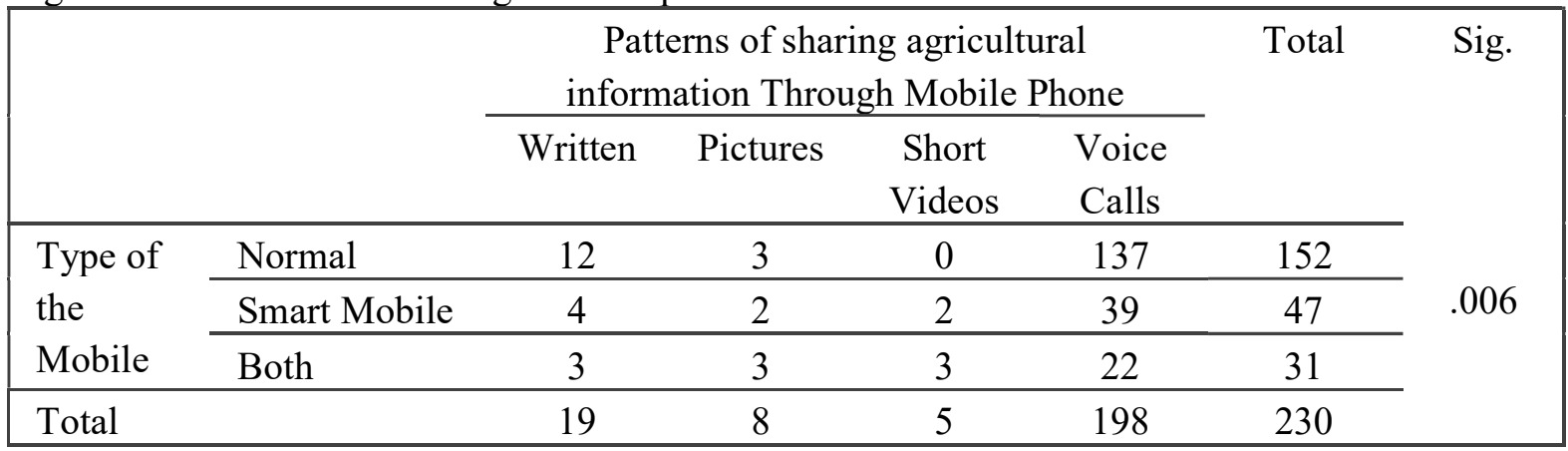

$P \leq 0.05=$ significant, indicating by Chi-square Test: source; field research 2018

$X^{2}$ value $=18.034$ 


\subsection{Advantages of using mobile phone}

The penetration of mobile service in Sudan has reached vast stakeholders, the results in figure 15 , depicted that $74.1 \%$ they used mobile phone for logistics, $47.9 \%$ for getting finance this result in line with [44] stated that agricultural development programs are bedeviled with many constraints like poor access of funding and production inputs among farmers, but in Ethiopia the farmers used mobile communication in marketing[45], 91.7\% for information regarding pests and diseases, $85.4 \%$ for price prediction, $98.5 \%$ for socialization, $44 \%$ for agricultural phenomena photographing, $78.9 \%$ for administration, $90.1 \%$ for risk avoidance and minimizing loss, and $94.9 \%$ for accessing urgent agricultural services, also result Professionals in the green industry can have access to pictures, information, and recommendations for managing weeds, diseases, and pests (e.g. Turf grass Management App)[46]. Also results extend to indicated that smart mobile phone have positive contribution towards income generation and farmers prefer to keep their phones and never sell its in case of emergencies, figures 16 and 17 respectively. Due to the above, policy makers, mobile network operators and media have touted the poverty eradicating potential of mobile phone communication. For example Vodafone Accenture (2011) reported that in a typical developing country, an increase of 10 mobile phones per 100 people boosts GDP growth by $6 \%$. Ashraf et al. (2008) notes that it is with this in mind that developing countries have been rushing to implement ambitious mobile phone for development projects in rural areas through direct or indirect supervision of institutions such as the World Bank, the United Nations (UN) and other donor/local agencies[47]. The results in table 9 revealed that there is a highly significant difference between using mobile phones in accessing agricultural information and agricultural revolution, this in line with [48] and [49] reported that developed ICT technologies have positive role in improving livelihood and sustainable smart agricultural production. Besides making access to knowledge and information cheaper, one more area in which mobile phones usage can aid the process of socioeconomic development in rural areas by bringing about an increase in per capita income and life skills and by facilitating poverty reduction. The adoption of this technology faces several challenges, however, such as the prevalence of illiteracy, power shortages, lack of trust and the high cost of smart phones[50] the other challenges were cited in table 10, such as Vanish of credit, make some inconvenience, vanish of phone battery, make some social problem, planning farm stealing, Know-how problem, network problems, difficult in dealing with technology, and dissemination fake news. 


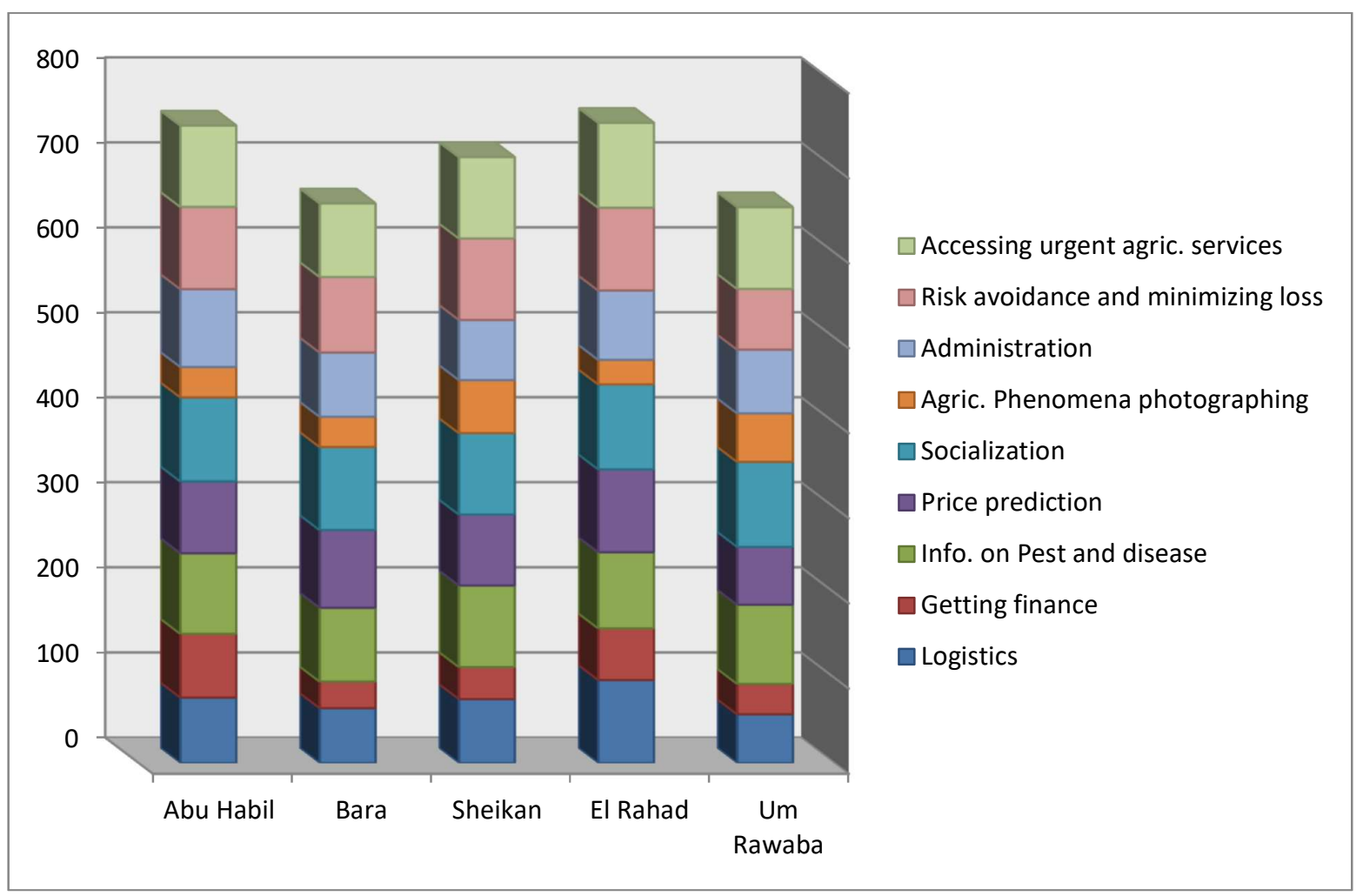

Figure 15. Diversified potential purposes of using mobile phone in agricultural field

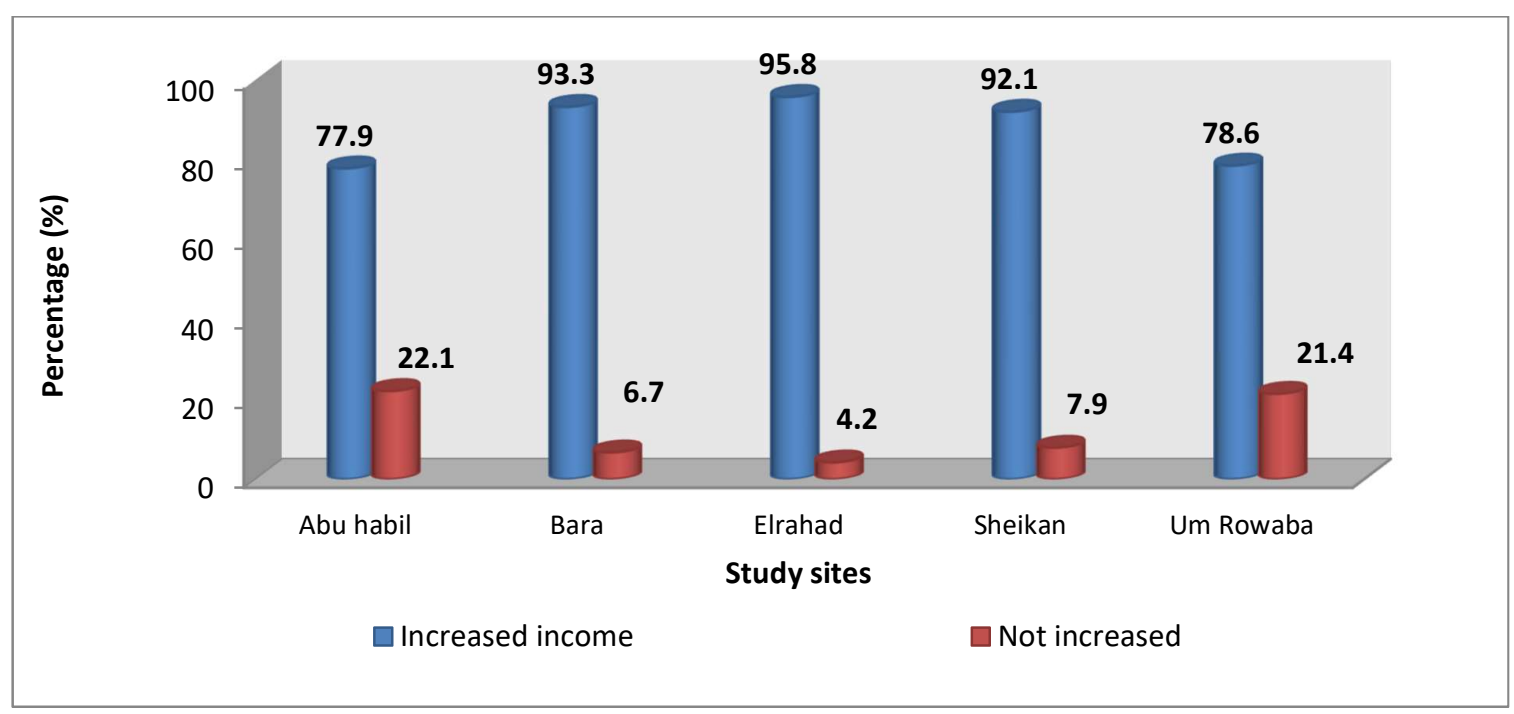

Figure 16.Farmer's perceptions toward contribution of smart-mobile phones in income generation 


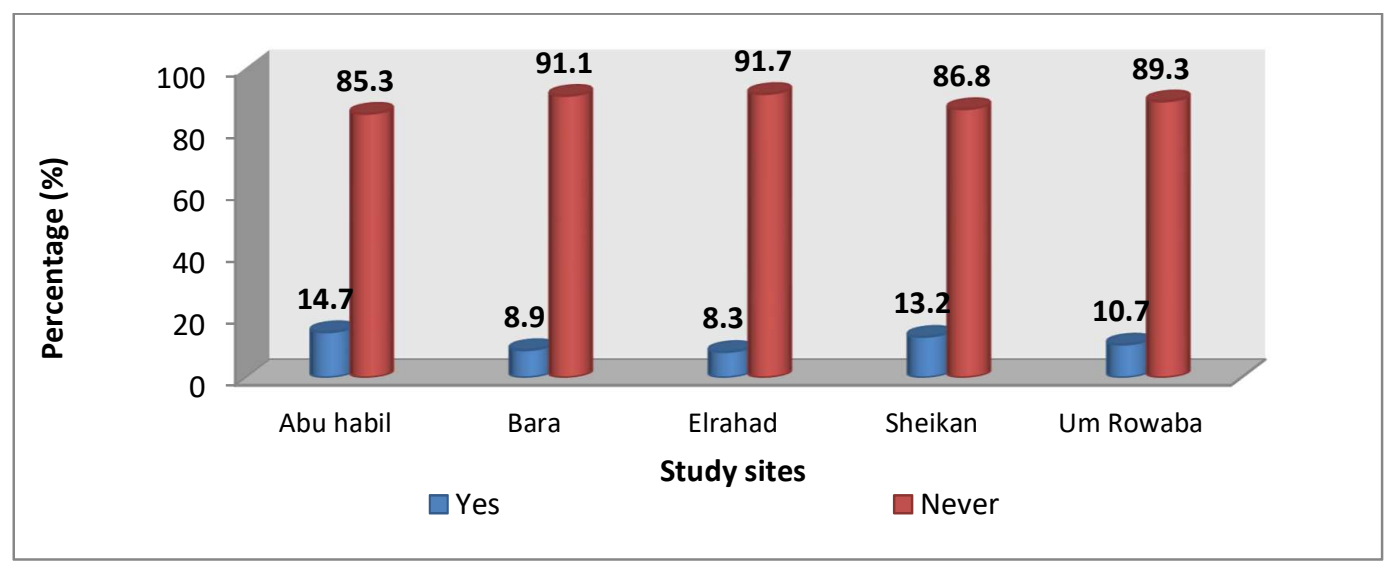

Figure 17. Possibility of selling the smart-mobile phones in case of emergencies

Table 9. Chi-square Test for significant between using mobile phones in accessing agricultural information and agricultural revolution

\begin{tabular}{|c|c|c|c|c|c|}
\hline & & \multicolumn{2}{|c|}{$\begin{array}{l}\text { Role of Mobile phones in } \\
\text { Agricultural Revolution }\end{array}$} & \multirow[t]{2}{*}{ Total } & \multirow[t]{2}{*}{ Sig. } \\
\hline & & Contributed & Not contributed & & \\
\hline Using Mobile & continues use & 200 & 4 & 204 & 0.001 \\
\hline $\begin{array}{l}\text { Accessing } \\
\text { Agricultural } \\
\text { Information }\end{array}$ & Often use & 21 & 5 & 26 & \\
\hline Total & & 221 & 9 & 230 & \\
\hline
\end{tabular}

$P \leq 0.05=$ significant, indicated by Chi-square Test: source; field research (2018)

$Z^{2}$ value $=18.293$

\subsection{Result of group discussion}

The results of table10 showed that the critical points from five group discussion conducted in the area, these were type of agricultural information accessed, advantages of using mobile phone (normal or smart), stakeholder's perception towards using the mobile phone, and main challenges face the farmers. The comprehensive discussion reflect the level of respondents awareness, on the other hand Doss (2003) found that lack of awareness is one of the main reasons for farmers not adopting the new technology [21] some studies suggest that the poorest and marginalized may in fact have the most to gain from the use of mobile phones due to a lack of alternative means of communication[48]. 
Table 10.Results of focus group discussion

\begin{tabular}{|c|c|c|c|}
\hline $\begin{array}{l}\text { Type of Agric. } \\
\text { Information accessed }\end{array}$ & $\begin{array}{l}\text { Advantages of using } \\
\text { mobile phone }\end{array}$ & $\begin{array}{l}\text { Perception } \\
\text { towards using } \\
\text { mobile phone }\end{array}$ & $\begin{array}{l}\text { Challenge of using } \\
\text { mobile phone }\end{array}$ \\
\hline 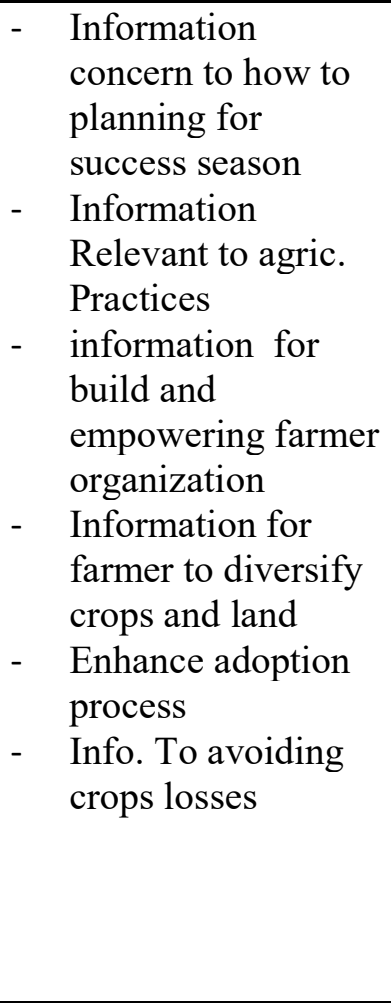 & $\begin{array}{ll}\text { - } & \text { Quick access to } \\
\text { logistic support } \\
\text { - } & \text { Quick access to } \\
\text { extension offices } \\
\text { - } & \text { Quick tell about pest } \\
\text { and diseases } \\
\text { - } \quad \text { Quick access to } \\
\text { police } \\
\text { - } \quad \text { Short way to labours } \\
\text { - } \quad \text { Enhance remote } \\
\text { marketing } \\
\text { - Facilitate } \\
\text { administration and } \\
\text { managerial issues } \\
\text { - Photographing } \\
\text { agricultural aspects } \\
\text { and phenomena } \\
\text { Socialization among } \\
\text { farmers } \\
\text { Ease communication } \\
\text { between farmers, } \\
\text { traders and end-users }\end{array}$ & $\begin{array}{l}\text { - Useful for } \\
\text { agricultural } \\
\text { revolution } \\
\text { - Good for farm } \\
\text { management } \\
\text { - Keep farmers } \\
\text { updated } \\
\text { - improving } \\
\text { understanding } \\
\text { and accelerate } \\
\text { adoption process } \\
\text { - Efficient in } \\
\text { solving problem } \\
\text { - Must be } \\
\text { propagate for all } \\
\text { farmers in the } \\
\text { rural area }\end{array}$ & $\begin{array}{ll}- & \text { Vanish of credit } \\
- & \text { Make some } \\
\text { inconvenience } \\
\text { - } & \text { Vanish of phone } \\
& \text { battery } \\
- & \text { Make some social } \\
\text { problem } \\
-\quad \text { Planning farm } \\
\text { stealing } \\
-\quad \text { Know-how problem } \\
- & \text { Network problems } \\
- & \text { Difficult in dealing } \\
\text { - } & \text { Dith technology } \\
\text { nissemination fake } & \text { news } \\
- & \text { High cost of smart } \\
\text { phones }\end{array}$ \\
\hline
\end{tabular}

Indicated by authors, field survey 2018

\section{Conclusion and recommendations}

The increasing penetration of mobile phones, especially in North Kordofan State could be a unique opportunity that could provide farmers with relevant information for their farming production. Using mobile phone enabled the farmers to have a positive impact on better gourd communicate with producer's network and improved farming community's awareness and cheaper source of getting information. Quantity and quality of accessed knowledge is not significantly affected with type of mobile phone. Majority of farmers have positive perception towards using mobile phones and they are still looking to connect other stakeholders with mobile phone. Main challenges that the rural communities have faced regarding using mobile phone were language barrier, vanish of credit, make some inconvenience, vanish of phone battery, make some social problem, planning farm stealing, Know-how problem, network problems, difficulties in dealing with technology, and dissemination fake news. The finding of this research will give insight to many extension service and policy makers to understand what farmers actually need. 
Farmers' information needs at various stages of crop production which were not clearly documented, therefore the study recommend that understanding farmers' information needs can result in provision of information services that better serve farmers' requirements, also connecting stallholders farmers with mobile phone and train them to use mobile phone at highest level to integrate this technology into rural livelihood activities.

\section{Acknowledgement}

This paper is based on study carried out under the younger research project financed by the Ministry of Higher Education and Scientific Research (MHESR), Sudan and applied by University of Kordofan, University of Gezira, and Peace University.

\section{References}

[1] A. Khan, U. Pervaiz, N. M. Khan, S. Ahmad, and S. Nigar, "Effectiveness of demonstration plots as extension method adopted by AKRSP for agricultural technology dissemination in District Chitral," Sarhad J. Agric., vol. 25, no. 2, pp. 313320, 2009.

[2] I. A. W. Mohamed, "assessement of the role of agriculture in Sudan economy," Elneelain Univ. Elneelain Univ., no. MPRA paper, 2011.

[3] François Laureys, "Use of ICT for Agriculture in GIZ projects - Status quo, opportunities and challenges," p. 143, 2016.

[4] J. Hellström, "Mobile phones for good governance - challenges and way forward," pp. 1-13, 2007.

[5] M. Tegegn, A. Dafisa, and A. Prof, "Review on Potential of Mobile Phone Usage in Agricultural Information Dissemination in Ethiopia," vol. 7, no. 12, pp. 63-75, 2017.

[6] F. Rehman, S. Muhammad, I. Ashraf, K. C. Mahmood, T. Ruby, and I. Bib, "Effect of farmers' socioeconomic characteristics on access to agricultural information: Empirical evidence from Pakistan,” J. Anim. Plant Sci., vol. 23, no. 1, pp. 324-329, 2013.

[7] S. F. G. Yusuf, P. Masika, and D. I. Ighodaro, "Agricultural Information Needs of Rural Women Farmers in Nkonkobe Municipality: The Extension Challenge," J. Agric. Sci., vol. 5, no. 5, 2013.

[8] N. Jehan, K. M. Aujla, and M. Shahzad, "USE OF MOBILE PHONES BY FARMING COMMUNITY AND ITS IMPACT ON VEGETABLE PRODUCTIVITY Naveed Jehan*, Khalid Mahmood Aujla**, Muhammad Shahzad*, Abid Hussain**, Muhammad Zahoor*, Majid Khan* and Ahmed Bilal*," Pakistan J. Agric. Resaerch, vol. 27, no. 1, 2014.

[9] K. Freeman, "ICT Use by Smallholder Farmers in Rural Mozambique: a Case Study of two Villages in Central Mozambique," J. Rural Soc. Sci., vol. 32, no. 2, pp. 1-19, 2017.

[10] J. K. Niemi, N. Minot, and M. Sell, "Use of mobile phones in agricultural marketing in Ghana and Uganda," Maatal. Päivät, 2016.

[11] W. Amir, M., Peter, N. \& Muluken, "The role of mobile phones in accessing agricultural information by smallholder farmers in Ethiopia," RUFORUM Work. Doc. Ser. (ISSN 1607-9345) No. 14 395-402. Available from http//repository.ruforum.org Res., vol. 14, no. 14, pp. 395-402, 2016. 
[12] M. R. Shaukat, I. A. Shah, and A. Shah, "Farmers Inclination to Adoption of Mobile Phone Agriculture Information and Trade Systems in Pakistan,” J. Econ. Soc. Stud., no. August 2013, 2013.

[13] F. Sousa, G. Nicolay, and R. Home, "Information technologies as a tool for agricultural extension and farmer- to-farmer exchange: Mobile-phone video use in Mali and Burkina Faso," Int. J. Educ. Dev. Using Inf. Commun. Technol., vol. 12, no. 3, pp. 1936, 2016.

[14] O. M. Akinnagbe and a R. Ajayi, "Challenges of Farmer-Led Extension Approaches in Nigeria,” World J. Agric. Sci., vol. 6, no. 4, pp. 353-359, 2010.

[15] R. A. Bolarinwa, K. K., and Oyeyinka, "Use of Cell Phone by Farmers and its Implication on Farmers 'Production Capacity i n Oyo State Nigeria," World Acad. Sci. Eng. Technol. Int. J. Biol. Food, Vet. Agric. Eng. Vol5, No3, 2011, vol. 5, no. 3, pp. 914, 2011.

[16] A. Elias, M. Nohmi, K. Yasunobu, A. Ishida, and A. D. Alene, "The effect of agricultural extension service on the technical efficiency of teff (Eragrostistef) producers in Ethiopia," Am. J. Appl. Sci., vol. 11, no. 2, pp. 223-239, 2013.

[17] S. Mittal, S. Gandhi, and G. Tripathi, "Working Paper No . 246 Socio-Economic Impact of Mobile Phones on Indian Agriculture," Agriculture, vol. 33, no. 246, p. 48, 2010.

[18] A. Hassan and O. Khalil, "Commitment on Extension Workers' Performance," Soc. Res. (New. York)., vol. Volume 1/4, pp. 368-87, 2008.

[19] Z. Kartika Ekasari et al., "Communication pattern and conflict in agricultural extension,” Asian Soc. Sci., vol. 9, no. 5, pp. 27-33, 2013.

[20] H. S. Kassem, "Effectiveness of different agricultural extension methods in providing knowledge and skills in disease prevention: a case of smallholder poultry production systems in Dakhalia Governorate of Egypt," Asian J. Agric. Extension, Econ. Sociol., vol. 3, no. 2, pp. 91-107, 2014.

[21] M. Islam, "Adoption of mobile phones among the farmers: A case study from rural Bangladesh," vol. 2011, pp. 1-20, 2011.

[22] F. Net, "SUDAN Livelihood Profiles, North Kordofan State August 2013," SUDAN Livelihood Profiles, North Kordofan State, no. August, 2013.

[23] M. A. A. Hamad, "Assessing Awareness and Perception on Food Quality and Safety among Households in Elobeid , North Kordofan-," vol. 6, no. 1, pp. 1-4, 2018.

[24] K. A. E. Zeinelabdein and A. E. M. Elsheikh, "Geophysical Investigations and Remote Sensing Techniques for Groundwater Exploration in Wadi Almilk Area, North Kordofan State, Sudan," Am. J. Earth Sci., vol. 2, no. 2, pp. 15-21, 2015.

[25] E. K. Makki and E. O. M. Musa, "A survey on draught animal technology (DAT) in EN-Nhoud area, North Kordofan State, Sudan," Trop. Anim. Health Prod., vol. 43, no. 5, pp. 923-928, 2011.

[26] I. A. Ishag, "Effect of Plant Maturity Stage on Digestibility and Distance Walked for Diet Selection by Goat at North Kordofan State, Sudan," vol. 13, no. 13, 2013.

[27] H. E. Adam, “Associate Prof. GIS Specialist University of Kordofan.” El Obeid, p. 1, 2018.

[28] S. Administration of innovation transfer and extension office, Ministry of Agriculture, North Kordofan State, "progress report," 2017.

[29] M. Ganesan, K. Karthikeyan, S. Prashant, and J. Umadikar, "Use of mobile multimedia agricultural advisory systems by Indian farmers : Results of a survey," J. Agric. Ext. Rural Dev., vol. 5, no. 4, pp. 89-99, 2013.

[30] I. Lambrecht, B. Vanlauwe, and M. Maertens, "Agricultural extension in Eastern Democratic Republic of Congo: does gender matter?," Eur. Rev. Agric. Econ., vol. 43, 
no. 5, pp. 841-874, 2016.

[31] A. Jellema, "Mobiles for Agricultural Development."

[32] M. M. Huq, K. Farhana, and A. Rahman, "Application of Mobile Phone in Agricultural Marketing in Bangladesh," IOSR J. Bus. Manag., vol. 19, no. 1, pp. 77-82, 2017.

[33] "Information in Tanzania : the Roles of Different," 2017.

[34] J. K. Niemi, N. Minot, and M. Sell, "Marketing of Agricultural Products and the Use of Mobile Phones Among Farm-Households in Ghana and Uganda : a Survey," pp. 468469, 2015.

[35] K. F. Masuki, J. Tukahirwa, and R. Kamugisha, "Mobile phones in agricultural information delivery for rural development in Eastern Africa : Lessons from Western Uganda," pp. 1-11, 2007.

[36] R. Anjum, "Design of mobile phone services to support farmers in developing countries," no. December, pp. 2-72, 2015.

[37] S. A. Cole and A. N. Fernando, "The Value of Advice: Evidence from Mobile PhoneBased Agricultural Extension," SSRN Electron. J., 2012.

[38] A. Verdier-chouchane and C. Karagueuzian, "Moving towards a green productive agriculture in Africa: The role of ICTs," vol. 7, no. 7, pp. 1-12, 2016.

[39] H. Baum, "Working Paper Series 93," no. May, 2012.

[40] F. Odhiambo, "Market In Their Palms ? Massey University Manawatu Campus New Zealand Fredrick Odhiambo Ajwang," 2016.

[41] F. W. Gatzweiler and J. Von Braun, "Technological and institutional innovations for marginalized smallholders in agricultural development," Technol. Institutional Innov. Marginalized Smallholders Agric. Dev., pp. 1-435, 2016.

[42] A. Crandall, "Kenyan Farmers' Use of Cell Phones: Calling preferred over SMS," M4D 2012, no. June, pp. 119-129, 2012.

[43] A. L. Henri, R. C. Noro, O. J. Julius, R. Fenosoa, and R. Jean, "Ownership and use of mobile phones for agricultural transactions by traders: The case of the Analanjirofo and Atsinanana Regions - Madagascar," J. Agric. Ext. Rural Dev., vol. 4, no. 10, pp. 305317, 2012.

[44] J. M. Chah, N. A. Ani, J. I. Irohibe, and A. . Agwu, "Creative Commons User Licence: CC BY-NC-ND," J. Agric. Ext., vol. 18, no. 2, pp. 10-20, 2012.

[45] K. M. Cho and D. J. Tobias, "Tropentag 2012, Göttingen, Germany September 19-21, 2012," pp. 1-10, 2012.

[46] S. Karetsos, "Developing a smartphone app for m-government in agriculture," J. Agric. Inform., vol. 5, no. 1, pp. 1-8, 2014.

[47] I. M. Mutunga and S. Lecturer, "Context of mobile phone use and its effects on smallholder farmer' s livelihood outcomes in Kenya," vol. 3, no. 4, pp. 121-136, 2016.

[48] H. Baumüller, "Agricultural Innovation and Service Delivery through Mobile Phones Analyses in Kenya Agricultural Innovation and Service," p. 156, 2015.

[49] B. L. Martin and E. Abbott, "Mobile Phones and Rural Livelihoods: Diffusion, Uses, and Perceived Impacts Among Farmers in Rural Uganda," Inf. Technol. Int. Dev., vol. 7, no. 4, p. .17-34, 2011.

[50] B. S. Mehta, Capabilities, Costs, Networks and Innovations: Impact of Mobile Phones in Rural India, no. April. 2013. 